\title{
Looking into the Credibility of Appearance: Exploring the Role of Color in Interface Aesthetics and How it Affects our Perception on System's Credibility
}

\author{
Achmad Syarief* \& Haruo Hibino** \\ * Industrial Design Research Division, Faculty of Arts and Design, Bandung Institute of \\ Technology \\ ** Design Psychology Research Division, Department of Design, Faculty of \\ Engineering, Chiba University
}

\begin{abstract}
Abstrak. Dalam penelitian ini dikaji hasil tiga eksperimen sebagai kelanjutan studi yang pernah dilakukan oleh Kurosu-Kashimura [1] dan Noam Tractinsky [2] tentang relasi antara persepsi pengguna dengan kualitas estetik dan usability tampilan interface. Berdasar dua premis utama yaitu bahwa persepsi estetik dipengaruhi latar belakang kultural serta tampilan yang atraktif dapat mempengaruhi persepsi kehandalan sebuah produk., Dalam penelitian ini dievaluasi bagaimana persepsi pengguna migran (:orang Indonesia yang berada di Jepang) terhadap relasi antara tampilan estetik dan apparent usability pada sebuah interface produk. Dalam eksperimen dilakukan investigasi efek tampilan warna pada sebuah interface produk terhadap persepsi trustworthy (tingkat kepercayaan) dan credibility (tingkat kredibilitas) produk secara umum. Sebagai stimulus, digunakan tampilan layout-utama (hasil modifikasi) layar ATM bank di Jepang.

Hasil eksperimen menunjukkan bahwa nilai estetik tampilan interface mempengaruhi persepsi user atas credibility (tingkat kredibilitas) dan trustworthy (tingkat kepercayaan) sebuah objek. Latar belakang budaya pengguna tidak memiliki pengaruh signifikan terhadap persepsi estetik tampilan interface apabila pengguna telah melakukan adaptasi eksperiential atau memiliki pengalaman interaksi dengan produk dengan komposisi layout sejenis. Lebih lanjut hasil penelitian menunjukkan bahwa warna memiliki pengaruh penting dalam meningkatkan kualitas ke-atraktif-an, persepsi kredibiltas (credibility), dan tingkat penerimaan (acceptability) pengguna (user). Eksperimen lebih lanjut perlu dilakukan untuk mengetahui bagaimana dan seperti apa sebuah kombinasi warna pada sebuah tampilan interface, dapat memiliki pengaruh yang bermakna pada keterpakaian sebuah produk.
\end{abstract}

Keywords: aesthetics; apparent usability; color; interface design; perceived credibility. 


\section{Introduction}

The role of aesthetics in human affairs has been widely documented ${ }^{[3]}$. Conventional wisdom says that it might relate to our appreciation and attitude toward computer systems as well, especially considering user interface design. Yet, several previous researches [4,5] tend to downplay the tendency among designers to emphasize the aesthetic elements of the user interface in concern that it might degrade usability. Perhaps, because the contribution of aesthetics on human-computer interaction are mainly placed within terms of facilitating information processing, not in terms of engaging the users in a pleasing experience. However, study by Kurosu-Kashimura--and later by Tractinsky-showed that interface aesthetics play a greater role in affecting system usability and acceptability than we might be willing to admit. Aesthetics affect people's perception of apparent usability, which in turn might influence longer terms attitudes toward the system. However, upon the notion that aesthetics perceptions are somewhat culturally dependent [6], we might reasonably expect that the affect of aesthetics on people's perception will be vary across cultures. It is possible that one system interface that is viewed by people from different cultural background, might be adopted differently.

However, judging perceptual differences toward the relationship between aesthetics and usability alone will not reach anything important, without understanding whether or not it has actual effect on overall system's credibility as well. A prominent HCI researcher, Donald A. Norman [7], says that attractive things make people feel good, which in turn make them think more creatively and thus ease their attitudes toward a system. This ease-ness brings positive attitude and assists users' affective system to interpret and to determine which things are good, bad, safe, trustworthy, credible, etc. Study by B.J. Fogg [8] reveals that people tend to judge a credibility of system appearance predominantly on its layout and other design aspects (i.e. colors, balance, etc.), suggesting that people tend to have initial judgment base on a object's visual appearance.

Eventually, both Norman and BJ Fogg's theories imply that users do not perceive aesthetics perception of an interface, perceive ease of use, and perceive credibility as a separate and independent entity, rather it hypothetically suggests that they might have a close relationship and could have effect on each other as well. Based upon these notions, the purpose of this initial study was set to experimentally explore migrant user' perceptions on usability and aesthetics of a local product interface. However, advancing from previous experiments by KK and Tractinsky which used grayscale only stimuli, this study employed both grayscale and colored stimuli in order to understand their impacts on interface 
aesthetics and how they might affect user's perception toward trustworthiness and credibility of a system's interface.

\section{$2 \quad$ Methodology}

\section{$2.1 \quad$ Subjects}

17 Indonesian students [13 males and 4 females] took part in this study. They are all students in various disciplines of study at Chiba University, Japan. Having to adopt color stimuli, participants were tested individually by Farnsworth 100 Hue Test for the examination of color discrimination. None of participants had any type of color deficiency, although they were grouped according to 3 (three) types of color discrimination level (11.7\% Low, 76.4\% Average, and $11.9 \%$ Superior).

\subsection{Design and Procedure}

\subsubsection{Study Materials}

Original study material (ATM layout) was provided by Prof. Masaaki Kurosu, which later developed into 30 (thirty) ATM interface layouts using a computerized application for experiment 1 . All layouts in experiment 1 include similar components and were differed only by how these components were arranged. One interface stimuli that rated high in the experiment 1 (on both usability and aesthetics), were later be used for experiment 2 and 3. In experiment 2 and 3, only 5 (five) alternative stimuli were used. All stimuli used similar components and arrangements and differed only by background and keypad colors. For background colors, the used colors are blue (with chromaticity coordinates of $x=0.268, y=0.296)$, green $(x=0.276, y=0.282)$, yellow $(x=0.303, y=0.333)$, red $(x=0.294, y=0.311)$, and purple $(x=0.276$, $y=0.282$ ). For keypad colors, the chromaticity coordinates are blue (with chromaticity coordinates of $x=0.255, y=0.274)$, green $(x=0.261, y=0.321)$, yellow ( $x=0.356, y=0.390)$, red $(x=0.396, y=0.334)$, and purple $(x=0.255$, $y=0.221)$. The color of orange $(x=0.494, y=0.436)$ is used for symbolic and safety buttons of all stimuli. All coordinates were measured by Minolta CS100 Chromameter. 


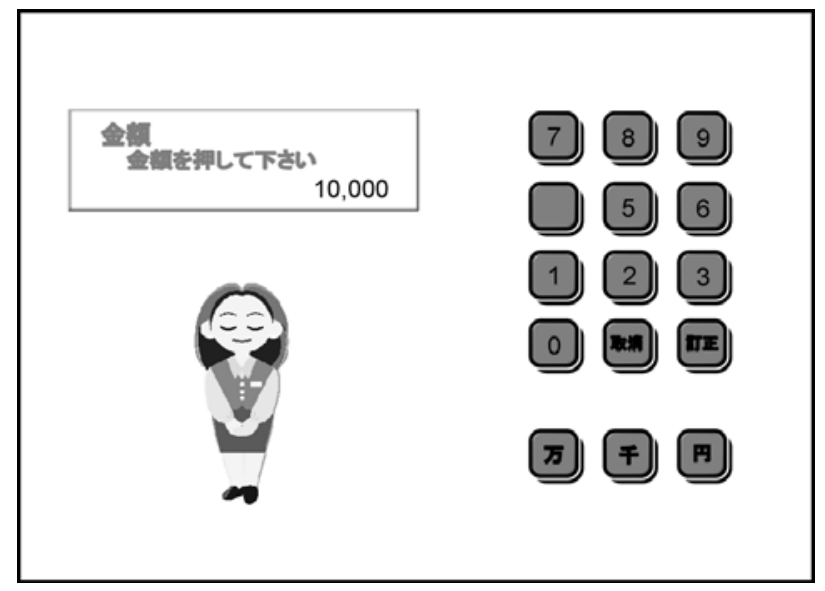

Figure 1 (a) Interface stimuli rated high on apparent usability and aesthetics.

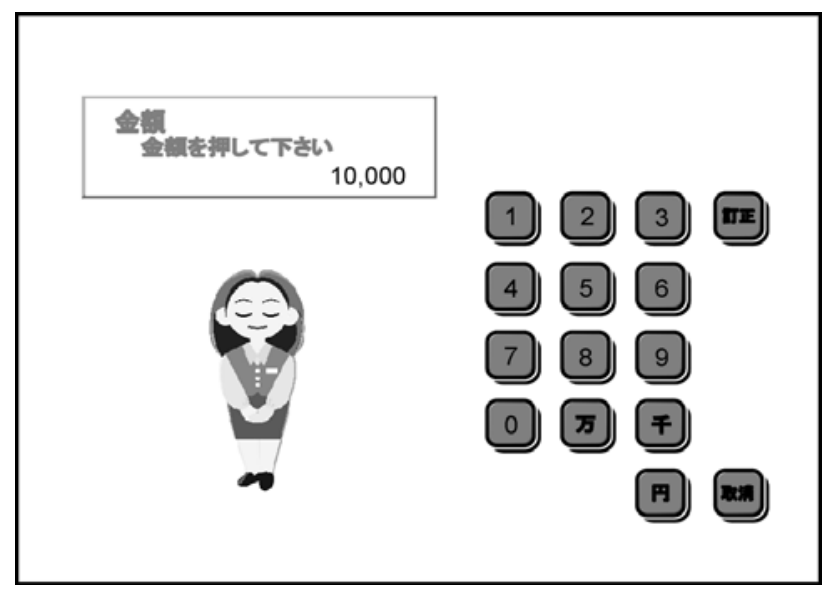

Figure 1 (b) Interface stimuli rated low on apparent usability and aesthetics.

\subsubsection{Variables}

For experiment 1 and 2, two independent variables (aesthetics and apparent usability) were operationalized by asking participants to rate each design on two 1-10 scales (1=lowest, $10=$ highest), concerning how easy it is to use and how beautiful it is. For experiment 3, a semantic differential (SD) test was operationalized by asking participants to rate each design on 8 (eight) pairs of adjective words based on 5 (five) level of subjective judgments, to map its significance with the word "credibility." These measures were modified based on the concept of credibility measures by McCroskey et al ${ }^{[9]}$. 


\subsubsection{Experiments} A. Experiment 1: Exploring the relationship between apparent usability
and aesthetics using grayscale stimuli

30 (thirty) interface stimuli on a computer monitor were presented individually to the participants on their convenient time set, with average 15-20 seconds per frame per subject. During that time, participant rated each layout on a 1 to 10 scale regarding how usable and beautiful it is to use and look at. All stimuli were assigned in random order to assure no individual biases.

\section{B. Experiment 2: Exploring the relationship between apparent usability and aesthetics using colored stimuli}

5 (five) different colored interface stimuli were presented individually to the participants on their convenient time set, with average of 15-20 seconds per frame per subject. During that time, participant rated each layout on a 1 to 10 scale regarding how usable and beautiful it is to use and look at. All stimuli were assigned in random order to assure no individual biases.

\section{Experiment 3: Profiling semantic differential image of credibility}

5 (five) different colored interface stimuli were presented to the participants. During that time, participant rated each layout regarding how each image subjectively appears to him/her. The test used a Semantic Differential (SD) profile consisting 8 (eight) pairs of adjective words in random order, to map its significance with the image "credibility". The SD profile for "credibility" consists of adjective word pairs of competence factors [consistent-inconsistent, reliable-unreliable, clear-unclear], trustworthiness factors [certain-uncertain, trustworthy-not trustworthy], and goodwill factors [complex-simple, attractivenot attractive, secure -insecure] ${ }^{[9]}$. Discussion of the meaning of each word were refrained and limited in order to avoid convention.

\section{$3 \quad$ Results and Discussions}

\subsection{Exploring the Relationship of Aesthetics and Apparent Usability on System's Interface to Cultural Variation}

Apparent usability scores ranged between 4.29 and 6.82 (5.648 in mean score) as compared to the scores of 4.4 to 6.5 (5.8 in mean score) in KurosuKashimura's study. As expected, the results were slightly lower than KK study, considering that the symbols and attributes were all written in Japanese. Aesthetics score ranged between 4.711 and 7.11 (6.099 in mean score) as 
compared to the score of 5.2 to 6.8 (6.0 in mean score) in Kurosu-Kashimura's study. Unexpectedly, the results were slightly higher than KK study, although all presented stimuli fully resembled those of Japanese ATM interfaces. The relationship between apparent usability and aesthetics were analyzed using correlational analysis.

Table 1 Correlations ( $\mathrm{p}<0.01)$ of aesthetics with apparent usability for experiment 1, KK's experiment in Japan and Tractinsky's experiment in Israel.

\begin{tabular}{|l|l|l|l|}
\hline \multirow{2}{*}{ Variable } & \multicolumn{3}{|l|}{ Correlation with Apparent Usability } \\
\cline { 2 - 4 } & Exp 1 & KK (Japan) & Tractinsky (Israel) \\
\hline Aesthetics & $\mathbf{0 . 7 0 8}$ & $\mathbf{0 . 5 8 9}$ & 0.921 \\
\hline
\end{tabular}

In general, the results resembled those obtained by KK (in Japan) and Tractinsky (in Israel). However, a higher coefficient result in this study compare to KK study (see Table 1), might suggest that Indonesian perceived ease of use and aesthetics to be more closely related. This is quite unexpected, given previous assumption that Indonesian students would be less sensitive to aesthetics aspects of the Japanese interface, considering notion that aesthetics perception are culturally dependent. On gender variable, the result shows that female tend to have higher coefficient correlation than male (0.144 and 0.6 respectively, with $\mathrm{p}<0.01$ ), suggesting that female perceived ease of use and aesthetics to be more closely related than male. On subject experience variable, both experienced and novice users have lower coefficient correlation (0.144 and 0.06 respectively with $\mathrm{p}<0.01$ ), suggesting that subject experiences is not as significant as previously given assumption. However, given the nature of limited number participants of this experiment, further studies are needed to confirm all of these premises.

\subsection{Exploring Potential Effect of Color on the Relationship between Apparent Usability and Aesthetics of System's Interface}

Apparent usability scores ranged between 5.824 and 7.00 (5.627 in mean score) while aesthetics scores ranged between 6.059 and 6.471 (5.688 in mean score). The relationship between apparent usability and aesthetics were analyzed using Spearman's rank (the coefficient of the correlation for interval scale) alongside corresponding correlation from experiment 1.

Table 2 Correlations $(\mathrm{p}<0.01)$ of aesthetics with apparent usability for experiment 2 and 1.

\begin{tabular}{|l|l|l|}
\hline \multirow{2}{*}{ Variable } & \multicolumn{2}{|l|}{ Correlation with Apparent Usability } \\
\cline { 2 - 3 } & Exp 1 (grayscale) & Exp 2 (colors) \\
\hline Aesthetics & $\mathbf{0 . 7 0 8}$ & $\mathbf{0 . 7 4 1}$ \\
\hline
\end{tabular}


Generally, the results resembled those obtained by experiment 1 . However, a slightly higher coefficient result in experiment 2 compared to experiment 1 (see Table 2), might suggest that users tend to acknowledge the role of colors more in the relationship of apparent usability and aesthetics aspect of interface design. This is very well expected, given assumption that colors could affect overall aesthetics impression of users than grayscale interface design. Colors provides visual contrast and harmony (see Figure 1), thus engages most of subjects to develop an inner sense of order when adopting them.

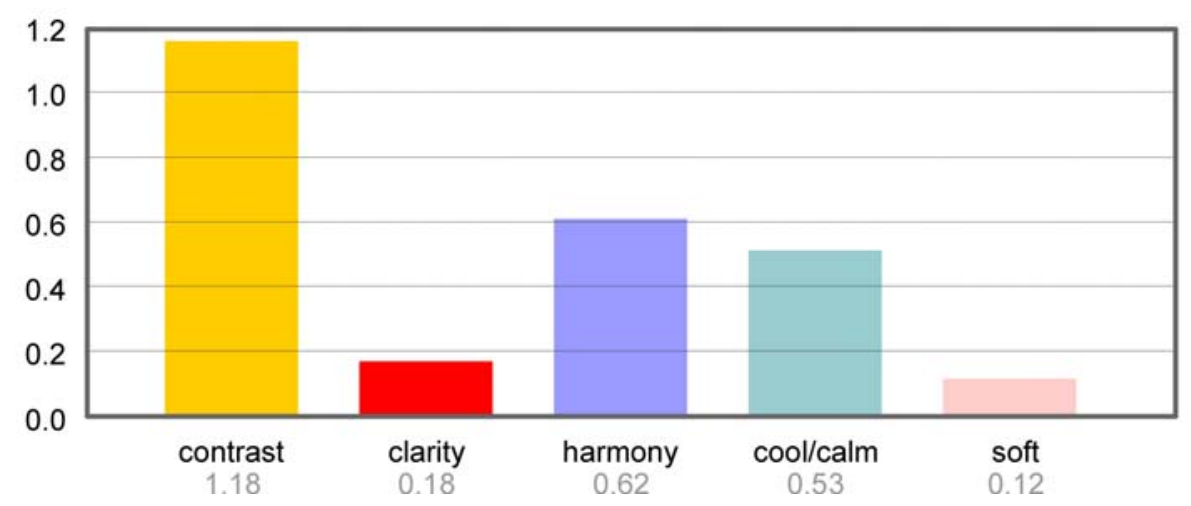

Figure 2 Reasons for choosing colored-stimuli.

\subsection{Exploring Potential Effect of Color on Perceived Credibility of System's Interface}

Results from semantic differential profile shows that colored stimuli are perceived to have more trust, more reliable, certainly more attractive, more clearer to adopt, gives more sense of certainty, more security assurance, and more consistent to their use than grayscale stimuli (see Figure 2). Following experiment 2, this result certainly support previous suggestion that colors could provide visual attractiveness and a sense of credibility.

All colored stimuli are better in enhancing visual attractiveness and engaging credibility, in comparison to grayscale stimuli. Yet, each stimulus have different affects on user' perceptions. Color combinations of red are perceived to have the most reliable and clearer image but tended to be inconsistent to look at. Color combinations of yellow are the most simplest image yet not attractive, color combinations of green are the most trustworthy but not clear enough to be understood, color combinations of blue are both reliable and consistent to look at , while color combinations of purple are having average responds. The following figure shows SD profile of perceived credibility according to each color combination. 


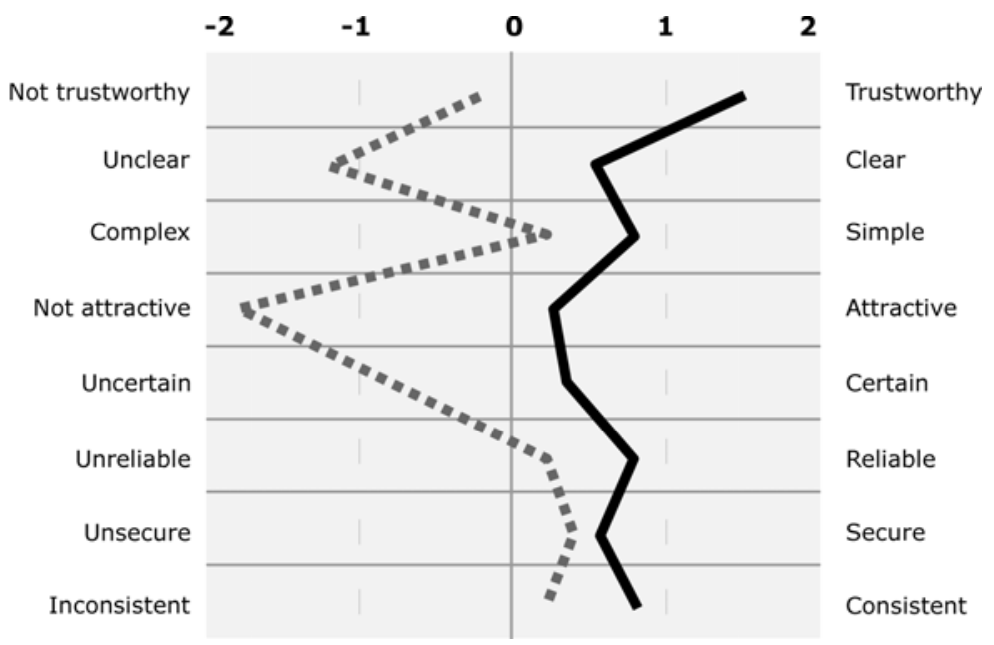

Figure 3 Comparison of S D profiles between colored interface and grayscale interface.

(Note:... grayscale stimuli $\longrightarrow$ color stimuli)

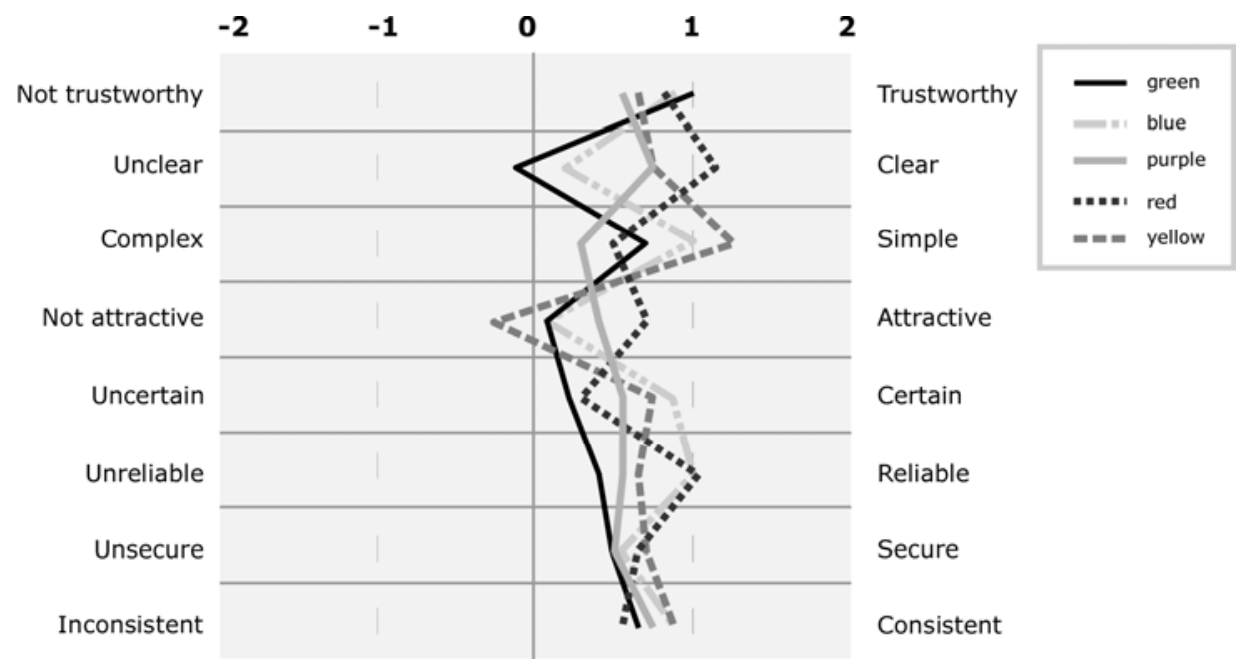

Figure 4 Comparison of S D profiles between each colored interface.

\section{Conclusions}

This study was designed to demonstrate that there is correlation between aesthetic and apparent usability of a system interface. It was expected that the correlations of migrant users would be lower than those obtained by previous study in Japan. Unexpectedly, the opposite result was obtained, which lead us to 
conclude that aesthetics perception and its relation to a system's usability are somewhat NOT culturally dependent. However, given that most subjects have at least 1 year experience of living in Japan further analysis need to be address to reaffirm contention. This study also designed to demonstrate that colors are potential elements to enhance interface aesthetics, assuming that the role of colors in interface aesthetics is to provide visual contrast and harmony, enabling users to have an inner sense of order when adopting them. As expected, result shows that colors provide more visual attractiveness and heighten the system's perceived credibility as compared to grayscale object. Each combination of colors shows that its image have better correlation with perceived credibility compare to grayscale, although actual effects are not known yet.

This leads to two major conclusions: First, the results provide further support for the contention that perceptions of interface aesthetic are closely related to apparent usability and thus increase the likelihood that aesthetics may considerably affect not only system acceptability but also its credibility as well. Second, colors have pivotal roles to enhance attractiveness, ensuring system acceptability and credibility, although further effort is needed to determine how and which color combinations are appropriately useful for system's interface design.

\section{References}

[1] Kurosu, Masaaki, and Kashimura, Kaori. 1995. Apparent usability vs. Inherent usability. CHI 1995 Conference Companion, pp. 292-293.

[2] Tractinsky, Noam. 1997. Aesthetics and Apparent Usability: Empirically Assessing Cultural and Methodological Issues. CHI 1997 Conference Proceedings, ACM, pp. 115-122.

[3] Maquet, J. 1986. The Aesthetics Experience. Yale University Press, New Haven-CT.

[4] Foley, J.D., A. Van Dam, Feiner, S.K., Hughes, J.F. 1990. Computer Graphics: Principles and Practice. $2^{\text {nd }}$ Edition. Addison-Wesley, Reading - MA.

[5] Marcus, A. 1992. Graphic Design for Electronic Documents and User Interfaces. ACM Press, NY.

[6] Fernandes, T. 1995. Global Interface Design. AP Professional.

[7] Norman, Donald A. 2004. Emotional Design: Why we love (or hate) everyday things. Basic Books, NY.

[8] Fogg, B.J. 2003. Persuasive Technology: Using computers to change what we think and do. Morgan-Kaufmann Publishers, NY.

[9] McCroskey, J.C., and Teven, J.J. 1999. Goodwill: A reexamination of the construct and its measurement. Communication Monographs, 66, pp. 90130. 